\title{
Effect of different levels of supplementation after weaning on beef heifer development
}

\author{
L.A. Foster ${ }^{1}$, P.J. Fourie ${ }^{1 \#} \&$ F.W.C. Neser ${ }^{2}$ \\ ${ }^{1}$ Department of Agriculture, Central University of Technology, Free State, Private Bag X20539, Bloemfontein, 9300, \\ South Africa \\ ${ }^{2}$ Department of Animal, Wildlife and Grassland Sciences, University of the Free Sate, P.O. Box 339, Bloemfontein \\ 9300, South Africa
}

(Received 5 December 2018; Accepted 4 January 2020; First published online 10 March 2020)

\author{
Copyright resides with the authors in terms of the Creative Commons Attribution 4.0 South African Licence. \\ See: https://creativecommons.org/licenses/by/4.0/za \\ Condition of use: The user may copy, distribute, transmit and adapt the work, but must recognise the authors and the South African \\ Journal of Animal Science.
}

\begin{abstract}
The purpose of the study was to identify a cost-effective supplementation regimen to rear replacement heifers on transitional Cymbopogon-Themeda veld. A total of 120 Drakensberger heifers aged $6-7$ months were randomly allocated to three supplementary treatment groups from 2011 - 2014. A three-phase supplementation programme was used while the production year was divided into three periods, namely summer (wet season) (approximately mid-December to March), winter (early dry season) (April to July), and late winter (late dry season) (August to approximately mid-December). The late winter treatments consisted of three levels of supplemental crude protein (CP), a percentage of protein derived from non-protein nitrogen (NPN) and metabolizable energy (ME), namely T1: $306 \mathrm{~g} \mathrm{CP} / \mathrm{kg}(47.4 \% \mathrm{NPN})+\mathrm{ME} 7.4 \mathrm{MJ} / \mathrm{kg} ; \mathrm{T2}: 329 \mathrm{~g}$ CP/kg (70.72\% NPN) + ME $6.89 \mathrm{MJ} / \mathrm{kg}$; and T3: $475 \mathrm{~g} \mathrm{CP} / \mathrm{kg}(95.86 \% \mathrm{NPN})+\mathrm{ME} \mathrm{2.4} \mathrm{MJ/kg.} \mathrm{In} \mathrm{summer,} \mathrm{T1}$ was supplemented with $164 \mathrm{~g} \mathrm{CP} / \mathrm{kg}(7 \% \mathrm{NPN})+\mathrm{ME} 9 \mathrm{MJ} / \mathrm{kg}+13 \mathrm{~g} \mathrm{P} / \mathrm{kg}$; T2 with Voermol Superfos with $150 \mathrm{~g} \mathrm{CP} / \mathrm{kg}(13.6 \% \mathrm{NPN}), \mathrm{ME} 0 \mathrm{MJ} / \mathrm{kg}$, and $50 \mathrm{~g} \mathrm{P} / \mathrm{kg} ; \mathrm{T3}: 0 \mathrm{~g} \mathrm{CP} / \mathrm{kg}, \mathrm{ME} 0 \mathrm{MJ} / \mathrm{kg}$, and $60 \mathrm{~g} \mathrm{P} / \mathrm{kg}$. The traits were nutrient intake, supplement cost, mean bodyweight, weight gains/losses and mean BCS. The study concluded that feeding replacement heifers to traditional bodyweight increased development costs without improving production sufficiently. Veld that is in good condition together with a mineral $(60 \mathrm{~g} \mathrm{P} / \mathrm{kg}$ ) supplement in the wet season and a protein and mineral supplement $(96 \% \mathrm{NPN})$ in the dry season gives the highest economic return.
\end{abstract}

Keywords: beef heifers, post wean, supplementation

${ }^{\#}$ Corresponding author: pfourie@cut.ac.za

\section{Introduction}

An adequate level of feed is necessary for good performance of heifers in their first and subsequent production cycles as cows (Wiltbank et al., 1984; Scholtz et al., 1991), whether they are mated at 12 - 14 months or at two years old. The effects of supplementation must be reflected in terms of animal production (De Brouwer et al., 1993). The parameters are positive bodyweight changes and increased reproduction. The returns must at least compensate for the costs incurred in feeding supplements (De Waal, 1990).

Regional differences in the age at which heifers are first exposed to breeding depend on management systems, forage quality and availability, and adaptation of breed to environmental conditions. The economic advantage of early breeding and calving in some cases is thwarted by the biological limitations of the animal and management constraints of the environment (Short et al., 1990). Most mechanisms of fertility, which influence calving and subsequent reproductive performance, are not highly heritable. It is therefore logical to assume that most factors that are associated with reproductive performance in cattle are influenced almost exclusively by management (Patterson et al., 2002). To a large extent, the management of replacement heifers in the post-weaning to pre-breeding period influences the times at which puberty, pregnancy, and parturition occur (Patterson et al., 2002).

The objective of the study was to identify a cost-effective supplementation regimen to rear replacement heifers in terms of the weight gains and BCS that are necessary to enable conception on transitional Cymbopogon-Themeda veld. 


\section{Material and Methods}

The study was conducted from August 2011 to July 2014 at Quaggafontein Farm, which is 3559 ha in size, and is situated $30 \mathrm{~km}$ south of Zastron in the south-eastern Free State, South Africa. The farm is located between $30^{\circ} 27^{\prime}$ south and $27^{\circ} 13^{\prime}$ east, at an altitude of between 1352 and 1626 metres above sea level. The average annual rainfall is $550 \mathrm{~mm}$. Summer temperatures are temperate and winters are cold, with frost occurring from the end of April until the beginning of October. The average daily temperatures by month are presented in Table 1. The vegetation is typical of transitional Cymbopogon-Themeda veld with a grazing capacity of 5 to 7 ha/animal unit.

Table 1 Average daily maximum and minimum temperatures by month from 1 August 2011 to 31 July 2014 for south-eastern Free State, South Africa

\begin{tabular}{lcccccc}
\hline \multirow{2}{*}{ Month } & \multicolumn{2}{c}{ August 2011 - July 2012 } & \multicolumn{2}{c}{ August 2012 - July 2013 } & \multicolumn{2}{c}{ August 2013 - July 2014 } \\
\cline { 2 - 6 } & $\operatorname{Max}\left({ }^{\circ} \mathrm{C}\right)$ & $\operatorname{Min}\left({ }^{\circ} \mathrm{C}\right)$ & $\operatorname{Max}\left({ }^{\circ} \mathrm{C}\right)$ & $\operatorname{Min}\left({ }^{\circ} \mathrm{C}\right)$ & $\operatorname{Max}\left({ }^{\circ} \mathrm{C}\right)$ & $\operatorname{Min}\left({ }^{\circ} \mathrm{C}\right)$ \\
\hline \multirow{2}{*}{ August } & & & & & & \\
September & 20.3 & 1.4 & 20.4 & 3.0 & 19.1 & 0.3 \\
October & 24.8 & 4.8 & 22.7 & 3.9 & 23.7 & 3.7 \\
November & 26.4 & 8.1 & 26.0 & 8.7 & 26.2 & 7.8 \\
December & 28.3 & 9.9 & 29.2 & 11.8 & 27.5 & 10.6 \\
January & 28.6 & 13.1 & 27.1 & 14.2 & 27.5 & 13.7 \\
February & 31.3 & 15.1 & 30.8 & 15.7 & 30.9 & 15.9 \\
March & 28.6 & 14.9 & 30.8 & 13.6 & 28.0 & 16.4 \\
April & 27.3 & 12.2 & 28.2 & 13.1 & 25.9 & 12.7 \\
May & 22.2 & 5.9 & 23.1 & 6.4 & 23.2 & 6.4 \\
June & 22.3 & 3.3 & 21.3 & 2.9 & 21.5 & 3.7 \\
July & 16.2 & 0.6 & 18.3 & -1.4 & 17.5 & -1.7 \\
& 17.2 & -0.9 & 19.1 & 0.9 & 17.0 & -2.6 \\
\hline
\end{tabular}

Source: South African Weather Service, 2015

Animal experimentation was conducted according to standard ethical norms (UFS/CUT Animal Ethics Clearance no. 26/2011). A total of 120 weaned Drakensberger heifers aged 6 - 7 months were used in the study. The animals were born and raised on the study site. Thirty-six animals participated in the study in Year 1 (2011 - 2012), 39 in Year 2 (2012 - 2013), and 45 in Year 3 (2013 - 2014).

A three-phase supplementation programme was used in which the production year was divided into three periods, namely summer (wet season) (approximately mid-December to March), winter (early dry season) (April to July), and late winter (late dry season) (August to approximately mid-December). The levels of supplementation were similar to those commonly recommended by animal nutritionists and often used by farmers. The level of energy supplementation for some of the treatments was low in relation to the animals' daily requirements. Nevertheless, this is typical of the levels that are used under practical farming conditions. Macro ingredients were mixed on site according to commercial supplementation formulations. The intakes of the supplements were recorded accurately at herd level. The supplements were available ad libitum, but never exceeded the maximum recommended daily intake. They were replenished twice a week to ensure that the animals had access to adequate supplies. Weekly weather forecasts of rainfall were considered in determining on which day supplements would be replenished. This was to prevent supplements that contained urea (NPN) from getting wet, which could affect intake and cause poisoning or death. Therefore, wet supplements were replaced.

The nutrient compositions and raw material inclusion rates of the three late winter treatments are presented in Table 2. These treatments consisted of three levels of supplemental $\mathrm{CP}$, percentage of protein derived from NPN and ME, as follows: T1: $306 \mathrm{~g} \mathrm{CP} / \mathrm{kg}(47.4 \% \mathrm{NPN})+\mathrm{ME} 7.4 \mathrm{MJ} / \mathrm{kg} ; \mathrm{T} 2: 329 \mathrm{~g} \mathrm{CP} / \mathrm{kg}$ $(70.72 \% \mathrm{NPN})+\mathrm{ME} 6.89 \mathrm{MJ} / \mathrm{kg}) ; \mathrm{T3}: 475 \mathrm{~g} \mathrm{CP} / \mathrm{kg}(95.86 \%$ ( NPN) + ME 2.4 MJ/kg. 
Table 2 Raw material inclusion rate (\%), nutrient composition and recommended daily intake (g/animal/day) of the late winter supplementation treatments for beef heifers

\begin{tabular}{lccc}
\hline & Treatment 1 & Treatment 2 & Treatment 3 \\
\hline & Raw material inclusion rate (\%) & \\
Maize meal & 28.50 & 37.34 & 18.46 \\
Cottonseed oilcake & 37.99 & 16.59 & - \\
Feed grade urea & 4.75 & 8.30 & 15.38 \\
Kimtrafos P12 & 7.12 & 8.30 & 15.38 \\
Kalori 3000 & 2.37 & 4.15 & 3.85 \\
Feed grade sulphur & 0.28 & 0.42 & 0.77 \\
Salt & 18.99 & 24.90 & 46.15 \\
& Nutrient composition & & \\
Crude protein (\%) & 30.60 & 32.91 & 47.51 \\
From NPN (\%) & 47.40 & 70.72 & 95.86 \\
ME (MJ/kg) & 7.40 & 6.89 & 2.40 \\
Calcium (\%) & 1.90 & 2.28 & 3.36 \\
Phosphorus (\%) & 1.30 & 1.25 & 2.57 \\
& Recommended daily intake (g/animal/day) & $290-340$ & $170-240$
\end{tabular}

Source: Van Pletzen, 2011. Voermol consultant, Bloemfontein Pers. Comm.

${ }^{1}$ Total phosphorus $12.3 \%$, Calcium: 20\%, Copper 0.03\% Manganese: 0.12\%, Zinc: $12 \%$, lodine: $30 \mathrm{mg} / \mathrm{kg}$, Selenium: 6 $\mathrm{mg} / \mathrm{kg}$, Cobalt: $6 \mathrm{mg} / \mathrm{kg}$

${ }^{2}$ Dried molasses-based powder with Crude protein: $9 \%$, Total phosphorus $0.25-0.40 \%$, Calcium $4.5-7.0 \%$

NPN: non-protein nitrogen; MJME/Kg DM: megajoules metabolizable energy per kilogram dry matter; P: phosphate

During the summer T1 was offered $164 \mathrm{~g} \mathrm{CP} / \mathrm{kg}(37 \% \mathrm{NPN})+\mathrm{ME} 9 \mathrm{MJ} / \mathrm{kg}+13 \mathrm{~g} \mathrm{P} / \mathrm{kg}$ with a recommended daily intake of 640 - $960 \mathrm{~g} /$ animal. T2 was supplemented with Voermol Superfos (Voermol, Tongaat) at $150 \mathrm{~g} \mathrm{CP} / \mathrm{kg}(13.6 \% \mathrm{NPN})+\mathrm{ME} 0 \mathrm{MJ} / \mathrm{kg}+50 \mathrm{~g} \mathrm{P} / \mathrm{kg}$ with a recommended daily intake of $80-$ $155 \mathrm{~g} / \mathrm{animal}$. T3 received with a supplement containing $0 \mathrm{~g} \mathrm{CP} / \mathrm{kg}, \mathrm{ME} 0 \mathrm{MJ} / \mathrm{kg}+60 \mathrm{~g} \mathrm{P} / \mathrm{kg}$ with a recommended daily intake of $190-270 \mathrm{~g} / \mathrm{animal}$. The nutrient composition and raw material inclusion rate of the summer treatments are presented in Table 3.

In winter all three treatment groups received the same supplement, namely $475 \mathrm{~g} \mathrm{CP} / \mathrm{kg}(95.86 \%$ NPN) + ME 2.4 MJ/kg) with a recommended daily intake of $190-270$ g/animal. The raw material inclusion rate and nutrient composition of the winter treatment are presented in Table 4.

The veld was managed according to the three-camp Elionurus cattle grazing system, which was developed by Van der Westhuizen (2014) and the stocking rate was maintained at 7.2 ha/animal unit. Groups were rotated between camps fortnightly to minimize a possible 'camp effect' on their performance. The parameters were supplement intake (g/heifer/day) and cost (R/heifer/year), weight (August, November, March and July) and BCS (scale 1 - 9).

Data were captured electronically in Microsoft Excel. Analyses were done with SAS Version 9.2. Frequencies and percentages were calculated for categorical data. Means and standard deviations or medians and percentiles were calculated for numerical data. Analyses of variance (ANOVA) were used to test main effects and the interaction of treatment with year. The unpaired t-test was used to compare the mean values and the mean differences between two treatment groups at a time. The paired t-test was used to investigate significant mean differences within each group. A significance level of 0.05 was used. 
Table 3 Raw material inclusion rate (\%), nutrient composition and recommended daily intake (g/animal/day) of the summer supplementation treatments for beef heifers

\begin{tabular}{|c|c|c|c|}
\hline & Treatment 1 & Treatment 2 & Treatment 3 \\
\hline \multicolumn{4}{|c|}{ Raw material inclusion rate (\%) } \\
\hline Voermol Superfos $\AA^{1}$ & - & 100 & - \\
\hline Maize meal & 55.78 & - & - \\
\hline Cottonseed oilcake & 15.94 & - & - \\
\hline Feed grade urea & 1.99 & - & - \\
\hline Kimtrafos $\mathrm{P} 12^{2}$ & 7.97 & - & 50.00 \\
\hline Kalori $3000^{3}$ & 1.99 & - & - \\
\hline Feed grade sulphur & 0.40 & - & 5.0 \\
\hline Salt & 15.94 & - & 45.00 \\
\hline \multicolumn{4}{|l|}{ Nutrient composition } \\
\hline Crude protein (\%) & 16.40 & 15.00 & - \\
\hline From NPN (\%) & 37.00 & 13.60 & - \\
\hline $\mathrm{ME}(\mathrm{MJ} / \mathrm{kg})$ & 9.00 & - & - \\
\hline $\mathrm{Ca}(\%)$ & 2.10 & 8.00 & 12.00 \\
\hline $\mathrm{P}(\%)$ & 1.30 & 5.00 & 6.00 \\
\hline \multicolumn{4}{|c|}{$\begin{array}{l}{ }^{1} \text { Crude protein: }>150 \mathrm{~g} / \mathrm{kg} \text {, Urea: }<47.4 \mathrm{~g} / \mathrm{kg} \text {, Moisture: }<120 \mathrm{~g} / \mathrm{kg} \text {, Calcium } 60-100 \mathrm{~g} / \mathrm{kg} \text {, Phosphorus }>50 \mathrm{~g} . \mathrm{kg} \text {, } \\
\text { Manganese: } 1200 \mathrm{mg} / \mathrm{kg} \text {, Copper: } 315 \mathrm{mg} / \mathrm{kg} \text {, Cobalt: } 11 \mathrm{mg} / \mathrm{kg} \text {, Iron: } 750 \mathrm{mg} / \mathrm{kg} \text {, lodine: } 25 \mathrm{mg} / \mathrm{kg} \text {, Zinc: } 1200 \mathrm{mg} / \mathrm{kg} \text {, } \\
\text { Selenium: } 10 \mathrm{mg} / \mathrm{kg} \\
2 \text { Total phosphorus } 12.3 \% \text {, Calcium: } 20 \% \text {, Copper } 0.03 \% \text { Manganese: } 0.12 \% \text {, Zinc: } 12 \% \text {, lodine: } 30 \mathrm{mg} / \mathrm{kg} \text {, Selenium: } 6 \\
\mathrm{mg} / \mathrm{kg} \text {, Cobalt: } 6 \mathrm{mg} / \mathrm{kg} \\
{ }^{3} \text { Dried molasses-based powder with Crude protein: } 9 \% \text {, Total phosphorus } 0.25-0.40 \% \text {, Calcium } 4.5-7.0 \% \\
\text { NPN: non-protein nitrogen; MJME } / \mathrm{Kg} \text { DM: megajoules metabolizable energy per kilogram dry matter; P: phosphate }\end{array}$} \\
\hline
\end{tabular}

Table 4 Raw material inclusion rate (\%), nutrient composition and recommended daily intake (g/animal/day) of the winter supplementation treatments for beef heifers

\begin{tabular}{|c|c|c|c|}
\hline & Treatment 1 & Treatment 2 & Treatment 3 \\
\hline \multicolumn{4}{|c|}{ Raw material inclusion rate (\%) } \\
\hline Maize meal & 18.46 & 18.46 & 18.46 \\
\hline Cottonseed oilcake & - & - & - \\
\hline Feed grade urea & 15.38 & 15.38 & 15.38 \\
\hline Kimtrafos $\mathrm{P} 12^{1}$ & 15.38 & 15.38 & 15.38 \\
\hline Kalori $3000^{2}$ & 3.85 & 3.85 & 3.85 \\
\hline Feed grade sulphur & 0.77 & 0.77 & 0.77 \\
\hline Salt & 46.15 & 46.15 & 46.15 \\
\hline \multicolumn{4}{|l|}{ Nutrient composition } \\
\hline Crude protein (\%) & 47.51 & 47.51 & 47.51 \\
\hline From NPN (\%) & 95.86 & 95.86 & 95.86 \\
\hline $\mathrm{ME}(\mathrm{MJ} / \mathrm{kg})$ & 2.40 & 2.4 & 2.4 \\
\hline $\mathrm{Ca}(\%)$ & 3.36 & 3.36 & 3.36 \\
\hline $\mathrm{P}(\%)$ & 2.57 & 2.57 & 2.57 \\
\hline
\end{tabular}




\section{Results and Discussion}

The three-year average supplement and nutrient intakes (g/animal/day) of the three groups during the study (2011-2014) and the three-year average costs incurred (R/animal/period) per supplementation period are presented in Table 5.

Table 5 Average supplement values, nutrient intakes and costs per supplementation period for beef heifers

\begin{tabular}{|c|c|c|c|c|c|c|c|c|c|}
\hline \multirow{2}{*}{$\begin{array}{l}\text { Component intake } \\
\text { (g/animal/day) }\end{array}$} & \multicolumn{3}{|c|}{ Late winter (137 days) } & \multicolumn{3}{|c|}{ Summer (106 days) } & \multicolumn{3}{|c|}{ Winter (123 days) } \\
\hline & $\mathrm{T} 1$ & $\mathrm{~T} 2$ & T3 & $\mathrm{T} 1$ & $\mathrm{~T} 2$ & T3 & $\mathrm{T} 1$ & $\mathrm{~T} 2$ & T3 \\
\hline Supplement & 657 & 299 & 167 & 380 & 100 & 64 & 192 & 192 & 192 \\
\hline Protein & 201 & 98 & 79 & 62 & 15 & 0 & 91 & 91 & 91 \\
\hline Protein from NPN & 95 & 69 & 76 & 23 & 13 & 0 & 87 & 87 & 87 \\
\hline MJME/Kg DM & 4.9 & 2.1 & 0.4 & 3.4 & 0 & 0 & 0.5 & 0.5 & 0.5 \\
\hline Phosphorus & 8.5 & 3.7 & 4.3 & 4.9 & 5.0 & 3.8 & 4.9 & 4.9 & 4.9 \\
\hline Cost (R/animal/period) & 286 & 116 & 59 & 114 & 47 & 21 & 65 & 65 & 65 \\
\hline Cost (R/animal/day) & 2.09 & 0.85 & 0.61 & 1.08 & 0.44 & 0.20 & 0.53 & 0.53 & 0.53 \\
\hline
\end{tabular}

T1: Treatment 1, T2: Treatment 2, T3: Treatment 3

NPN: non-protein nitrogen; MJME/Kg DM: megajoules metabolizable energy per kilogram dry matter

The three late winter periods lasted an average of 137 days. The average daily late winter supplement intake was T1: 657 g/animal/day (201 g CP); T2: 299 g/animal/day 98 g CP); and T3: 167 g/animal/day (79 g $\mathrm{CP})$. The three-year average costs per animal that were incurred in supplying the late winter supplement were R286 for T1; R116 for T2; and R59 for T3 (Table 5).

The summer supplementation periods lasted an average of 106 days. In this time (Table 5) T1 consumed an average of $380 \mathrm{~g}$ supplement/animal/day, which supplied $62 \mathrm{~g} \mathrm{CP}$ and $4.9 \mathrm{~g} \mathrm{P}$ per animal per day. T2 consumed an average of $100 \mathrm{~g}$ supplement/animal/day, which supplied $15 \mathrm{~g} \mathrm{CP}$ and $5.0 \mathrm{~g} \mathrm{P}$ per animal per day. T3 consumed an average of $64 \mathrm{~g}$ supplement/animal/day, which supplied $0 \mathrm{~g} \mathrm{CP}$ and $3.8 \mathrm{~g}$ $\mathrm{P}$ per animal per day. The three-year average costs per animal that were incurred in supplying the summer supplement were R114 for Treatment 1, R47 for Treatment 2, and R21 for Treatment 3.

All three groups received the same supplement during winter supplementation. The average intake was $192 \mathrm{~g}$ per animal per day, which supplied $91 \mathrm{~g} \mathrm{CP}$ and $4.9 \mathrm{~g} \mathrm{P}$ per animal per day.

Means of bodyweight $(\mathrm{kg})$ and weight change for the groups are presented in Table 6 . Body condition scores (BCS) are similarly presented in Table 7. Year had a marked influence on the effect of supplementation on performance of the three groups. It was assumed that variations in total rainfall and rainfall distribution between years, which affected the availability of grazeable roughage in certain periods of the study, was the reason that year had an effect on the growth.

In Year 1, no differences $(P>0.05)$ were measured in total weight gain, end weight (winter weight) and end BCS (winter BCS) between the groups.

In Year 2 the total weight gain of T2 $(P<0.05)$ was more than that of T3. The end weights of T1 and T2 were more $(P<0.05)$ than that of T3. In spite of the recovery growth exhibited by T3 in the spring of Year 2 , the animals in this group were not able to keep up with the rate of total weight gain shown by T1 and T2. The period of lower weight gain by T3 compared with T1 and T2 coincided with a shortage in grazeable material. No differences in BCS were measured between treatment groups in Year 2 (see Table 6).

In Year 3, T1 gained $(P<0.01)$ more weight than T2 and T3. Thus, at the end of the season T1 weighed more $(P<0.05)$ than T2 and T3. The results from Year 2 and Year 3 agree with the findings of several researchers who recorded higher feed intakes in cattle than would normally be expected in periods of readjustment (Horton \& Holmes, 1978; Baker et al., 1985). It is therefore obvious that complete recovery is not possible if grass is in short supply during the readjustment phase (as in Years 2 and 3).

Total annual cost of supplementation per animal was R466.00 for T1, R228.28 for T2, and R145.30 for T3. 
Table 6 Mean bodyweights and weight gains/losses of the different supplementation treatment groups from August 2011 to July 2014

\begin{tabular}{|c|c|c|c|}
\hline & Treatment 1 & Treatment 2 & Treatment 3 \\
\hline & Mean weight $(\mathrm{kg})$ & Mean weight (kg) & Mean weight $(\mathrm{kg})$ \\
\hline \multicolumn{4}{|c|}{1 August 2011 to 31 July 2012} \\
\hline & $n=12$ & $n=12$ & $\mathrm{n}=12$ \\
\hline Late winter (Aug) & $234^{\mathrm{a}} \pm 17$ & $220^{b} \pm 13$ & $223^{\mathrm{ab}} \pm 12$ \\
\hline Spring (Nov) & $279^{a} \pm 18$ & $261^{b} \pm 15$ & $271^{\mathrm{ab}} \pm 16$ \\
\hline Summer (Mar) & $344^{\mathrm{a}} \pm 19$ & $327^{\mathrm{ab}} \pm 21$ & $323^{b} \pm 21$ \\
\hline Winter (Jul) & $360 \pm 21$ & $350 \pm 28$ & $343 \pm 19$ \\
\hline Weight gain Aug to Nov & $45^{\mathrm{ab}} \pm 9$ & $41^{a} \pm 6$ & $48^{\mathrm{b}} \pm 7$ \\
\hline Total weight gain & $125 \pm 10$ & $130 \pm 13$ & $120 \pm 12$ \\
\hline \multicolumn{4}{|c|}{1 August 2012 to 31 July 2013} \\
\hline & $\mathrm{n}=13$ & $\mathrm{n}=12$ & $\mathrm{n}=14$ \\
\hline Late winter (Aug) & $232^{a} \pm 26$ & $215^{\mathrm{ab}} \pm 14$ & $209^{b} \pm 18$ \\
\hline Spring (Nov) & $268 \pm 34$ & $264 \pm 16$ & $257 \pm 22$ \\
\hline Summer (Mar) & $369^{a} \pm 33$ & $357^{a} \pm 23$ & $\star 334^{b} \pm 23$ \\
\hline Winter (Jul) & $361^{a} \pm 43$ & $351^{a} \pm 27$ & $328^{b} \pm 27$ \\
\hline Weight gain Aug to Nov & $* 36^{a} \pm 13$ & $49^{b} \pm 7$ & $48^{\mathrm{b}} \pm 7$ \\
\hline Total weight gain & $129^{\mathrm{ab}} \pm 20$ & $136^{a} \pm 20$ & $119^{b} \pm 14$ \\
\hline \multicolumn{4}{|c|}{1 August 2013 to 31 July 2014} \\
\hline & $\mathrm{n}=15$ & $\mathrm{n}=15$ & $\mathrm{n}=15$ \\
\hline Late winter (Aug) & $214 \pm 15$ & $214 \pm 13$ & $212 \pm 11$ \\
\hline Spring (Nov) & $\star \star 253^{a} \pm 17$ & $229^{b} \pm 14$ & $228^{\mathrm{b}} \pm 17$ \\
\hline Summer (Mar) & $* 354^{\mathrm{a}} \pm 19$ & $329^{b} \pm 18$ & $327^{b} \pm 20$ \\
\hline Winter (Jul) & $356^{\mathrm{a}} \pm 22$ & $334^{\mathrm{b}} \pm 23$ & $328^{b} \pm 19$ \\
\hline Weight gain Aug to Nov & $\star \star \star 39^{\mathrm{a}} \pm 6$ & $9^{b} \pm 5$ & $16^{\mathrm{c}} \pm 9$ \\
\hline Total weight gain & $\star 142^{\mathrm{a}} \pm 18$ & $120^{b} \pm 16$ & $115^{b} \pm 12$ \\
\hline
\end{tabular}

${ }^{\mathrm{ab}}$ Mean values in the same row with different superscripts differ significantly: $P<0.05$; $P<0.01$;

${ }^{\star \star} P<0.001 ;{ }^{* \star *} P<0.0001$

The T1 group, which received supplements that were higher in ME and had a lower fraction of protein from NPN sources in late winter (see Tables 2, 3, and 4), had consistently higher BCS than T2 and T3. However, the difference was not always significant.

The combined production and economic data underline the importance of selecting the correct rearing strategy for replacement heifers. The results of this research suggest that the optimum supplementation strategy for raising heifers in a year of normal rainfall grazing of transitional CymbopogonThemeda veld that is in good condition would be T3. When rainfall and availability of grazeable roughage become limiting factors, better production is attained by supplementing heifers with T2 and T3. Owing to the high intakes and thus costs of the supplements offered to T1, animals that received these supplements would have to perform considerably better as first-calf heifers and cows than those that were raised on the regimens offered to T2 and T3.

Protein is an essential ingredient of a winter and late maintenance supplement (Hennessy, 1983; Van Niekerk \& Jacobs, 1985; Groenewald, 1986; McCosker et al., 1991; De Brouwer et al., 1993; and Van Niekerk, 1996) because it is the most important limiting nutrient in winter. Although the intake of the winter supplement (192 g/animal/day) was far below the recommended daily intake of $270-380 \mathrm{~g} / \mathrm{animal}$ per day, it would appear that animal production was not adversely affected because the groups were able to gain weight during this period. 
Table 7 Mean body condition score of the supplementation treatment groups from August 2011 to July 2014

\begin{tabular}{|c|c|c|c|}
\hline & Treatment 1 & Treatment 2 & Treatment 3 \\
\hline & Mean BCS & Mean BCS & Mean BCS \\
\hline \multicolumn{4}{|c|}{1 August 2011 to 31 July 2012} \\
\hline & $\mathrm{n}=12$ & $n=12$ & $\mathrm{n}=12$ \\
\hline Late winter (Aug) & $\star \star 4.58^{\mathrm{a}} \pm 0.51$ & $3.42^{b} \pm 0.51$ & $3.08^{b} \pm 0.29$ \\
\hline Spring (Nov) & $\star \star 5.83^{\mathrm{a}} \pm 0.39$ & $5.00^{b} \pm 0.00$ & $4.92^{b} \pm 0.67$ \\
\hline Summer (Mar) & $6.08^{a} \pm 0.29$ & $5.92^{a} \pm 0.29$ & $5.83^{a} \pm 0.39$ \\
\hline Winter (Jul) & $4.17^{a} \pm 0.39$ & $3.92^{\mathrm{a}} \pm 0.29$ & $4.00^{\mathrm{a}} \pm 0.00$ \\
\hline \multicolumn{4}{|c|}{1 August 2012 to 31 July 2013} \\
\hline & $\mathrm{n}=13$ & $\mathrm{n}=12$ & $\mathrm{n}=14$ \\
\hline Late winter (Aug) & $4.08^{a} \pm 0.28$ & $4.00^{\mathrm{a}} \pm 0.00$ & $4.00^{a} \pm 0.00$ \\
\hline Spring (Nov) & $4.69^{a} \pm 0.63$ & $4.58^{\mathrm{a}} \pm 0.51$ & $4.86^{a} \pm 0.36$ \\
\hline Summer (Mar) & $6.00^{\mathrm{a}} \pm 0.58$ & $6.00^{\mathrm{a}} \pm 0.42$ & $5.86^{a} \pm 0.53$ \\
\hline Winter (Jul) & $5.23^{a} \pm 0.60$ & $5.00^{a} \pm 0.43$ & $5.00^{a} \pm 0.55$ \\
\hline \multicolumn{4}{|c|}{1 August 2013 to 31 July 2014} \\
\hline & $\mathrm{n}=15$ & $\mathrm{n}=15$ & $\mathrm{n}=15$ \\
\hline Late winter (Aug) & $5.00^{a} \pm 0.00$ & $5.00^{a} \pm 0.00$ & $5.00^{a} \pm 0.00$ \\
\hline Spring (Nov) & $* 4.60^{a} \pm 0.51$ & $4.13^{b} \pm 0.35$ & $4.53^{a} \pm 0.52$ \\
\hline Summer (Mar) & $6.73^{a} \pm 0.46$ & $6.73^{a} \pm 0.46$ & $6.67^{a} \pm 0.49$ \\
\hline Winter (Jul) & $4.33^{a} \pm 0.49$ & $4.20^{a} \pm 0.56$ & $4.27^{\mathrm{a}} \pm 0.46$ \\
\hline
\end{tabular}

Phosphorus supplementation has become general practice in South Africa (Van Niekerk \& Jacobs, 1985; Groenewald, 1986; Read et al., 1986a; Read et al., 1986b; De Waal, 1990, De Brouwer et al., 1993; De Waal et al., 1996; Van Niekerk, 1996; De Brouwer et al., 2000). The average daily intakes of supplemental $P$ in summer were $4.9 \mathrm{~g} /$ animal/day for T1; $5.0 \mathrm{~g} / \mathrm{animal} / \mathrm{day}$ for T2, and $3.8 \mathrm{~g} / \mathrm{animal} / \mathrm{day}$ for T3. Only T3 consumed levels of $P$ below the recommended minimum (Van Pletzen, 2011) of 5.1g P per animal per day. A possible reason for the low intake of supplemental P for T3 could be well-conserved veld. But to what extent would these results be replicated under conditions of overgrazing, which are common?

The bodyweights at the end of each year of all three groups over the three-year period were well within the optimum weight range (Meaker et al., 1980; Dreyer, 1982; BIF 1990; Lepen et al., 1991; Lynch et al., 1997). This calls for feeding heifers to pre-breeding weights that represent $60 \%$ to $65 \%$ of the animals' projected mature weight. Only when heifers reach the genetically predetermined weight, can high pregnancy rates be obtained (Lynch et al., 1997). Dreyer (1982) and Lepen et al. (1991) established that Drakensberger heifers reached puberty at an average weight of $300 \mathrm{~kg}$.

A body condition score of 5 to 6 is considered ideal for heifers at breeding. Fleck et al. (1980) and Ferrell (1982) indicated that the condition of heifers during the postweaning period influenced first-exposure pregnancy rates and those that were thin or fat prior to the breeding season had more difficulty in conceiving. Nolan et al. (1998) and Armstrong et al. (2001) agreed that a high plane of nutrition was detrimental to oocyte quality in nulliparous heifers with moderately high BCS. Furthermore, low post-fertilization developmental rates were recorded in these heifers. Adamiak et al. (2005) concluded that the effects of the level of feeding on oocyte quality were dependent on the body condition of the animal. High levels of feeding improved post-fertilization development for animals in low BCS but reduced it for animals with good BCS. The effects of high levels of feeding were also cumulative, with blastocyst yields for heifers in moderately good body condition deteriorating over time relative to heifers in low body condition. Adamiak et al. (2005) also produced evidence that moderately fat animals on a high level of feeding were hyperinsulinemic and that those with very high plasma insulin concentrations were associated with impaired oocyte quality.

At the conclusion of each production year none of the three groups was capable of reaching the target breeding BCS of 5 to 6 (see Table 7). However, the groups were exposed to a bull only in the following November. It would therefore be important to ensure that heifers should gain sufficient body fat on spring 
grazing before they were bred. These results agree with the findings of Clanton et al. (1993), Lynch et al. (1997), Grings et al. (1999), Funston et al. (2012), and Endecott et al. (2013), who concluded that recovery growth periods could be utilized and provide an opportunity to decrease feed costs.

Studies from multiple locations indicated that restricting the bodyweight of developing heifers on dormant winter forage increased economic advantages, potentially creating animals that were better suited to maintaining themselves as cows compared with programmes that developed heifers to a greater target bodyweight (Endecott et al., 2013).

\section{Conclusions}

Feeding replacement heifers to attain traditional bodyweight targets increased development costs without improving their productivity. South-eastern Free State veld that is in good condition and is well managed gives the highest economic return from supplementing replacement heifers with a mineral $(60 \mathrm{~g}$ $\mathrm{P} / \mathrm{kg}$ ) supplement in the wet season and a protein and mineral supplement, of which $96 \%$ of the protein is derived from NPN, in the dry season. However, the importance of adequate available roughage during recovery growth cannot be overemphasized. Different results may be obtained with other breed types.

\section{Acknowledgements}

The authors wish to acknowledge the inputs of the late Mr Hendrik van Pletzen and Mr Johan Mouton.

\section{Authors' Contributions}

The trial was executed by LAF, while PJF and FWCN provided supervision.

\section{Conflict of Interest Declaration}

The authors declare that there is no conflict of interest and specifically do not endorse any of the commercial supplements that were utilized in this study.

\section{References}

Adamiak, S.J., Mackie, K., Watt, R.G., Webb, R. \& Sinclair, K.D., 2005. Impact of nutrition on oocyte quality: Cumulative effects of body composition and diet leading to hyperinsulinemia in cattle. Biol. Repro. 73, 918-926.

Armstrong, D.G., McEvoy, T.G., Baxter, G., Robinson, J.J., Hogg, C.O., Woad, K.J., Webb, R. \& Sinclair, K.D., 2001. Effect of dietary energy and protein on bovine follicular dynamics and embryo production in vitro: Associations with ovarian insulin-like growth factor system. Biol. Repro. 64, 1624-1632.

Baker, R.D., Young, N.E. \& Laws, J.A., 1985. Changes in body composition of cattle exhibiting compensatory growth and the modifying effects of grazing management. Anim. Prod. 41, 309-321.

BIF (Beef Improvement Federation), 1990. Guidelines for uniform beef improvement programs. 6th edition. Oklahoma State University, Stillwater, Oklahoma.

Clanton, D.C., Jones, L.E. \& England, M.E., 1983. Effect of rate and time of gain after weaning on the development of replacement heifers. J. Anim. Sci. 56(2), 280-285.

De Brouwer, C.H.M., Visser, C.B., Schutte, A.R. \& Postma, M., 1993. Biological and economical effects of different supplements given to beef cows on summer veld. S Afr. J. Anim. Sci. 23(2), 31-37.

De Brouwer, C.H.M., Cilliers, J.W., Vermaak, L.M., Van Der Merwe, H.J. \& Groenewald, P.C.N., 2000. Phosphorus supplementation to natural pasture for beef cows in the western Highveld region of South Africa. S. Afr. J. Anim. Sci. 30(1), 43-52.

De Waal, H.O., 1990. Review: Animal production from native pasture (veld) in the Free State region - A perspective of the grazing ruminant. S. Afr. J. Anim. Sci. 20(1), 1-9.

De Waal, H.O., Randall, J.H. \& Koekemoer, G.J., 1996. The effects of phosphorus supplementation on body mass and reproduction of grazing beef cows supplemented with different levels of phosphorus at Armhoedsvlakte. S. Afr. J. Anim. Sci. 26(2), 29-36.

Dreyer, C.J., 1982. Die teelstruktuur van die Drakensberger en faktore wat die doeltreffendheid van produkise beinvloed. D.Sc. (Agric) proefskrif, Universiteit van Pretoria.

Endecott, R.L., Funstont, R.N., Mullinks, J.T. \& Roberts, A.J., 2013. Implications of beef heifer development systems and lifetime productivity. J. Anim. Sci. 91(3), 1329-1335.

Ferrell, C.L., 1982. Effects of postweaning rate of gain on onset of puberty and productive performance of heifers of different breeds. J. Anim. Sci. 55, 1272.

Fleck, A.T., Schalles, R.R. \& Kiracofe, G.H., 1980. Effects of growth rate through 30 months on reproductive performance beef heifers. J. Anim. Sci. 51, 816.

Funston, R.N., Martin, J.L., Larson, D.M. \& Roberts, A.J., 2012. Nutritional aspects of developing replacement heifers. J. Anim. Sci. 90(4), 1166-1171.

Grings, E.E., Staigmiller, R.B., Short, R.E., Bellows, R.A. \& MacNeil, M.D., 1999. Effects of nutritional management on trace mineral supplementation, and Norgestomet implant on attainment of puberty in beef heifers. J. Anim. Sci. 77, 810-815.

Groenewald, I.D., 1986. Die invloed van stikstof-, energie- en fosforbevattende lekaanvullings op die reproduksie- en produksievermoë van koeie op natuurlike weiding. PhD. thesis, University of the Orange Free State, Bloemfontein. 
Hennessy, D.W., 1983. Improved production from grazing cattle when given protein. S. Afr. J. Anim. Sci. 1983, 13(1), 911.

Horton, G.M.J. \& Holmes, W., 1978. Compensatory growth by beef cattle at grassland or an alfalfa-based diet. J. Anim. Sci. 46, 297.

Lepen, J.M., Schoeman, S.J. \& Venter, H.A.W., 1991. Die invloed van voedingspeil op puberiteitsbereiking by Nguni, Bonsmara en Drakensberger verse. S. Afr. J. Anim. Sci. 21(1), 43-47.

Lynch, J.M., Lamb, G.C., Miller, B.L., Brandt, R.T., Cochran, R.C. \& Minton, J.E., 1997. Influence of timing of gain on growth and reproductive performance of beef replacement heifers. J. Anim. Sci. 75, 1715-1722.

McCosker, T.H., O'Rourke, P.K. \& Eggington, A.R., 1991. Effects of providing supplements during the wet season on beef production in the Darwin district of the Northern Territory. The Rangeland Journal 13(1), 3-13.

Meaker, H.J., Coetsee, T.P.N. \& Lishman, A.W., 1980. The effects of age at first calving on the productive and reproductive performance of beef cows. S. Afr. J. Anim. Sci. 10, 105-113.

Nolan, R., O'Callaghan, D., Duby, R.T., Lonegran, P. \& Boland, M.P., 1998. The influence of short-term nutrient changes on follicle growth and embryo production following superovulation in beef heifers. Theriogenology 50, 1263-1274.

Patterson, D.J., Wood. S.L. \& Randle, R.F., 2002. Procedures that support reproductive management of replacement beef heifers. Proc. Appl. Reprod. Strategies in Beef Cattle, 29-30 August 2017, Manhattan, Kansas.

Read, M.V.P., Engels, E.A.N. \& Smith, W.A., 1986a. Phosphorus and the grazing ruminant. 2. The effects of supplementary P on cattle at Glen and Armoedsvlakte. S. Afr. J. Anim. Sci. 16(1), 7-12.

Read, M.V.P., Engels, E.A.N. \& Smith, W.A., 1986b. Phosphorus and the grazing ruminant. 3. Rib bone samples as an indicator of the P status of cattle. S. Afr. J. Anim. Sci. 16(1), 13-17.

Scholtz, M.M, Lombard, P.E. \& Enslin C.B., 1991. A note on the early calving of beef heifers. S. Afr. J. Anim. Sci. 21(4), 206-209.

Short, R.E., Staigmiller, R.B., Bellows, R.A. \& Greer, R.C., 1990. Breeding heifers at one year of age: Biological and economic considerations. In: Proc. 39th Ann. Beef Cattle short course, 93-106. University of Florida, Gainesville.

Van der Westhuizen, H.C., 2014. Evaluering van onderskeie veldbestuursbenaderings. Boer saam met die natuur op soetgrasveld. In: H.A. Snyman (ed.) Gids tot die volhoubare produksie van weiding. Tweede uitgawe. Kaapstad: Landbouweekblad en Landbou.com, Media 24, 127-131.

Van Niekerk, B.D.H., 1996. Limiting nutrients in supplementary feeding. Bull. Grassland Soc. Southern Africa 7(1), 51-59.

Van Niekerk, B.D.H. \& Jacobs, G.A., 1985. Protein, energy and phosphorus supplementation of cattle fed low-quality forage. S. Afr. J. Anim. Sci. 15(4), 133-136.

Van Niekerk, A. \& Kernick, R., 1990. Effect of winter nutritional levels on subsequent growth of beef heifers in the Highland Sourveld of Natal. S. Afr. J. Anim. Sci. 20(2), 84-89.

Wiltbank, J.N., Roberts, S., Nix, J. \& Rowden, L., 1984. Reproductive performance and profitability of heifers fed to weigh 272 or $318 \mathrm{~kg}$ at the start of the breeding season. J. Anim. Sci., 60, 25-34. 